\section{TRAM-LINE CALCIFICATION IN RENAL CORTICAL NECROSIS}

\author{
BY
}

\section{H. G. LLOYD-THOMAS, M.D., M.R.C.P.}

R. H. BALME, D.M., M.R.C.P.

AND

\section{J. J. KEY, M.B., B.Ch., D.M.R.D.}

From the Medical Unit and the Radiological Department, London Hospital

[With Special Plate]

Bilateral renal cortical necrosis is a rare cause of acute oliguric renal failure. It most often arises in association with retroplacental haemorrhage. There may be no means of differential diagnosis between renal tubular necrosis and renal cortical necrosis except the response to therapy. Percutaneous renal biopsy may yield a specimen showing the features of renal cortical necrosis, but in some centres the use of this method during the oliguric stage of acute renal failure is avoided. Even so, the demonstration of the histological changes of renal cortical necrosis in the biopsy specimen does not entail a fatal prognosis. Five cases in which biopsy specimens showed these changes during the oliguric phase and the patient survived have been recorded (Crook, 1927 ; Gormsen et al., 1955 ; Ober et al., 1956 ; Boucot et al., 1957; Lauler and Schreiner, 1958). Survival in these cases is due to the patchy distribution of the areas of cortical necrosis with sparing of a sufficient amount of cortex to allow life to continue. Furthermore Sheehan and Moore (1952), in a study of 67 cases of fatal concealed accidental haemorrhage, found that patients with only a small amount of actual renal cortical necrosis may die in anuria as a result of damage to the tubular portion of the kidney. It is probable that in some at least of the fatal cases recorded in the literature the patient would not have died if current concepts of the management of acute oliguria had been applied.

In necropsy specimens certain authors have observed calcification of tubules and sometimes of glomeruli in or close to areas of renal cortical necrosis at various times up to 18 days after the onset of necrosis (Klotz, 1908 ; Jardine and Teacher, 1911 ; Geipel, 1925; Scriver and Oertel, 1930 ; Wolfson, 1932 ; Kellar and Arnott, 1933 ; Ash, 1933 ; Grasby, 1947 ; Akerren, 1947). Lauler and Schreiner (1958) reported a patient who died on the 24th day after the onset of acute renal failure, with necrosis of the entire cortex except for a few scattered areas, which were intensely congested. Microscopically, there were diffuse areas of calcification, haemorrhage, and white-cell infiltration. The necrotic glomeruli were calcified. However, none of the cases of renal cortical necrosis examined at necropsy by Sheehan and Moore (1952) showed microscopical calcification, nor did any of the 13 fatal cases similarly examined by Wells $e t$ al. (1960).

The radiological demonstration of renal calcification during life in cases of renal cortical necrosis has been reported, but more rarely (Alwall et al., 1958 ; De Graeff and De Baan, 1959; McAlister and Nedelman, 1961). Gormsen et al. (1955) described a picture of diffuse calcinosis in the peripheral parts of the cortices of both kidneys seen in tomograms taken 61 days after the onset of acute renal failure, during which time there was a period of total anuria. Needle biopsies, both from the right kidney, taken on the seventh and on the eleventh days showed that most of the cortical tissue obtained was necrotic. This patient survived, and nine months later had a 24-hour creatinine clearance of $29 \mathrm{ml}$. per minute. Moëll (1957) was able to examine serial radiographs from a patient who died of widespread renal cortical necrosis 116 days after the onset of oliguria. At 20 days there were large renal shadows. After a further 14 days the shadows had decreased in size and their outlines had become irregular. At seven weeks there was a further decrease in renal size and cortical calcification was present.

The case reported below showed a radiological pattern never previously described, and probably peculiar to diffuse renal cortical necrosis. The increasingly common application of modern principles of management to cases of acute renal failure and the referral of these cases to centres equipped for artificial dialysis make it likely that with more prolonged survival further examples of this kind of cortical calcification will be found.

\section{Case Report}

A 26-year-old pregnant woman with no history of previous illness was admitted to hospital because of lower abdominal pain and a large loss of blood per vaginam, the haemoglobin level falling to $35 \%$. The lowest recorded blood-pressure was $115 / 80 \mathrm{~mm}$. Hg. The uterus was not tender. Following abortion of a 26-weeks foetus approximately $20 \mathrm{oz}$. (568 ml.) of old blood-clot was passed. On catheterizing the bladder immediately after the abortion $60 \mathrm{ml}$. of urine containing a large amount of protein was obtained. For the next eight days the daily output of urine measured 1-30 ml., and because of this she was transferred to the London Hospital. The urine secreted on the ninth day measured $132 \mathrm{ml}$.; it contained sodium $74 \mathrm{mEq} / \mathrm{l}$., potassium $9 \mathrm{mEq} / 1$., urea $1.8 \mathrm{~g} . / 1$., a large amount of protein, and many red cells, but no excess of leucocytes or casts and no pathogenic organisms on culture. The plasma contained sodium 134 , potassium 7.4 , chloride 87 , and bicarbonate $12 \mathrm{mEq} / 1$.; calcium 8.2, phosphorus 11.6, and urea $105 \mathrm{mg} . / 100 \mathrm{ml}$. A basic fluid intake of $400 \mathrm{ml}$. a day was allowed. The acidosis was corrected by oral sodium lactate and the hyperkalaemia by enemata of sodium-phase ion-exchange resin. An anabolic steroid was given (norethandrolone, $10 \mathrm{mg}$. thrice daily). By the 16 th day after the abortion the plasma urea had risen to $420 \mathrm{mg} . / 100 \mathrm{ml}$., with plasma K 5.7, $\mathrm{Na} 137, \mathrm{HCO}_{3} 21, \mathrm{Cl} 71 \mathrm{mEq} / 1$. ; $\mathrm{Ca} 6.7$ and phosphate $20.5 \mathrm{mg} . / 100 \mathrm{ml}$. She had become drowsy. After six hours' dialysis (Kolff twin-coil artificial kidney) the plasma urea had fallen to $90 \mathrm{mg} . / 100 \mathrm{ml}$., with $\mathrm{Na} \mathrm{137}$, $\mathrm{K} 5.2, \mathrm{HCO}_{3} 28, \mathrm{Cl} 83 \mathrm{mEq} / 1$; $\mathrm{Ca} 11.8$ and phosphate 7.0 $\mathrm{mg} . / 100 \mathrm{ml}$. Water removed by ultrafiltration $(2,400 \mathrm{ml}$.) was replaced during the procedure by an equal volume of blood. A diet containing $100 \mathrm{~g}$. carbohydrate. 4-12 g. protein, and under $5 \mathrm{mEq}$ potassium per day was better tolerated than $10 \%$ lactose solution by mouth. The output of urine remained below $50 \mathrm{ml}$. per day, usually below $20 \mathrm{ml}$. per day and often only 3-5 ml. per day. By the 37 th day the plasma urea had risen to $320 \mathrm{mg} . / 100 \mathrm{ml}$., with plasma $\mathrm{K} \mathrm{4.1,} \mathrm{Na} 132, \mathrm{HCO}_{3} 17, \mathrm{Cl} 86 \mathrm{mEq} / \mathrm{l}$.; $\mathrm{Ca} 9.6$ and phosphate $14.1 \mathrm{mg} . / 100 \mathrm{ml}$. The plasma urea fell to $115 \mathrm{mg} . /$ $100 \mathrm{ml}$. after a second dialysis. Some features of the clinical course are shown in the accompanying chart.

Radiographs of the kidneys, which are described in detail below, were taken on the 40th day of anuria. Because it was considered that there was no real prospect of recovery, further dialysis was not carried out, and the patient died on 
the 55th day after the onset. Apart from a sore upper lip which became transiently infected with a penicillin-resistant staphylococcus late in the course of the illness, the general physical condition of the patient was remarkably good.

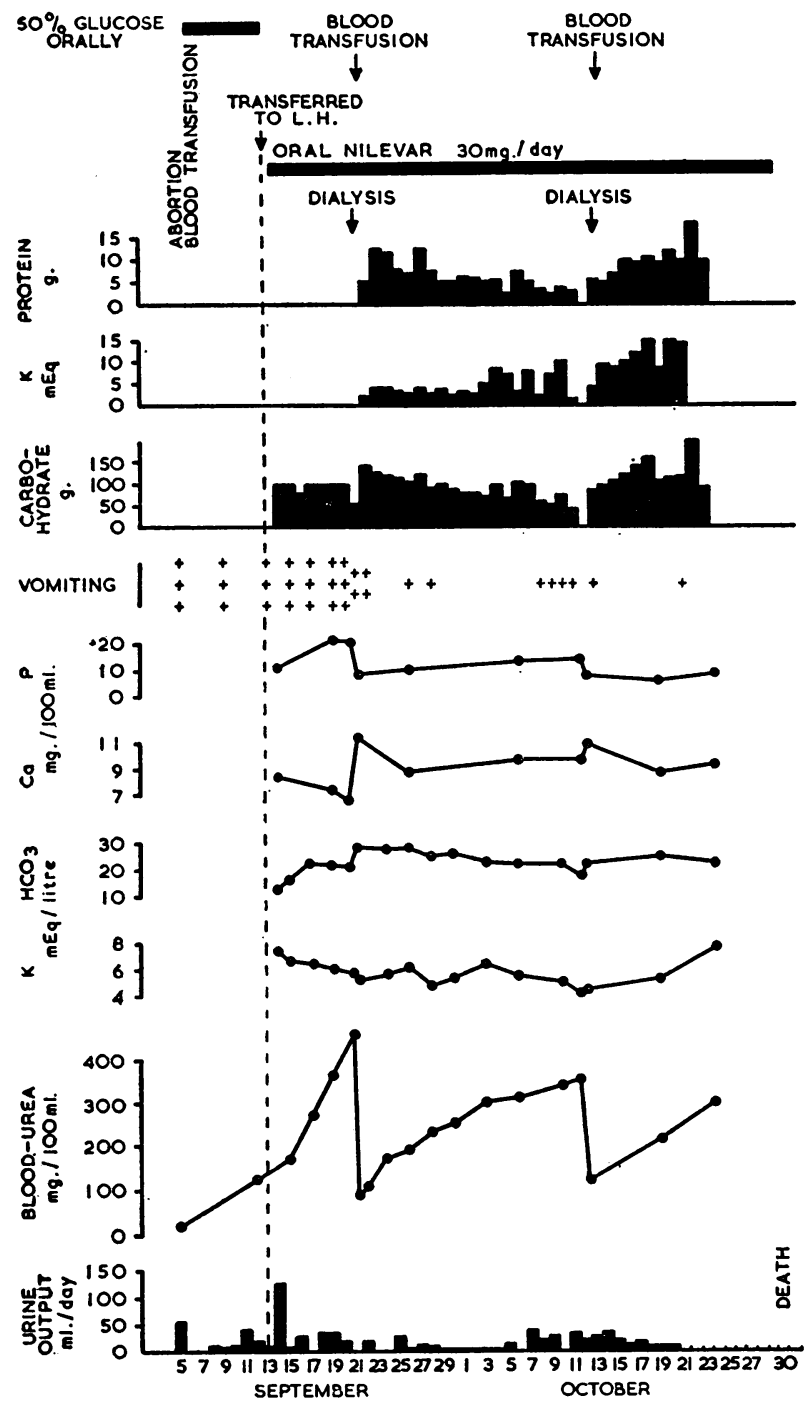

Chart showing clinical progress. From above downwards are recorded: (1) some details of treatment: (2) protein intake in g. $/ 24$ hours; (3) potassium intake in $\mathrm{mEq} / 24$ hours; (4) carbohydrate intake in g./24 hours; (5) frequency of vomiting; (6) serum phosphate cencentration in $\mathrm{mg} . / 100 \mathrm{ml}$.; (7) serum calcium concentration in $\mathrm{mg} . / 100 \mathrm{ml}$.; (8) serum bicarbonate concentration in $\mathrm{mEq} / 1$; (9) serum potassium concentration in $\mathrm{mEq} / 1$; ; (10) plasma urea in $\mathrm{mg} . / 100 \mathrm{ml}$.; (11) urine output in $\mathrm{ml} . / 24$ hours.

\section{X-ray Findings}

A plain film of the abdomen 31 days after the onset of anuria showed calcification of both renal shadows with a double-line pattern in the cortex. There was calcification in the region of the ureters and uterus.

Tomography seven days later showed dense speckled calcification of the renal cortices in a double-line pattern resembling a tram-line, with extension into the interlobular septa (Special Plate, Fig. 1). Calcification in relation to the course of the ureters was subsequently shown to be due to calcification in the thrombosed ovarian veins. The kidney shadows measure $4.5 \times 7.8 \mathrm{~cm}$. on the left and $4.8 \times 8 \mathrm{~cm}$. on the right, compared with normal values ranging upward from $5.6 \times 12 \mathrm{~cm}$. (Moëll, 1956 ; Hodson, 1959).

A post-mortem radiograph shows these changes more clearly (Special Plate, Fig. 2).

\section{Histological Findings}

The macroscopic appearance of one of the kidneys is shown in Special Plate, Fig. 3. The capsule of the kidney was slightly thickened. The cortex showed two bands of calcification, one subcapsular, the other juxtamedullary (Special Plate, Fig. 4). In the intervening cortex the renal tissue was completely necrotic. Some interlobular arteries were occluded by organized and sometimes calcified thrombus; in others the walls were necrotic and showed round-cell infiltration with gross dilatation (Special Plate, Fig. 5).

\section{Discussion}

The possibility that bilateral renal cortical necrosis may be the underlying cause of acute renal failure raises the question of what may be accepted as proof of this diagnosis. Material removed by needle biopsy will provide histological evidence of changes affecting the area of kidney from which the sample is taken, but this technique by itself cannot provide a definite clue to the total distribution of such changes. The development of diffuse renal calcinosis or of a calcified renal cortical shell after an episode of anuria may suggest that bilateral renal cortical necrosis is present and that the areas of necrosis are widespread throughout both kidneys. The combination of biopsy findings and the development of diffuse calcinosis probably provides firmer evidence, the former giving evidence of the nature of the pathological process and the latter of its extent. The case reported by Gormsen et al. (1955) showed biopsy evidence of renal cortical necrosis and later developed diffuse calcinosis, but, even so, enough renal tissue remained for the patient to survive the illness. Two other patients with biopsy proof of renal cortical necrosis have recovered (Boucot et al., 1957 ; Lauler and Schreiner, 1958), but neither developed renal calcification, perhaps because of the limited amount of necrotic renal tissue. Calcification of the renal parenchyma primarily involving the cortex has been described in relation to chronic glomerulonephritis by Arons et al. (1955), but without the clear tram-line pattern here reported. The calcification in our case with its doubleline pattern, following the cortical outline, immediately suggests severe renal damage. It seems likely that the calcification has occurred from two directions dependent upon the narrow rim of intact subcapsular cortex and the intact medulla. The narrow space separating the two lines of calcification and the width of each band suggest that little, if any, cortical tissue has survived. Comparison of the radiographs with the photomicrograph shows this relationship.

The routine use of tomography of the renal areas in cases of acute renal failure may lead to the recognition of the peculiar radiological pattern in further cases, bearing in mind that when obstetric cases are excluded there is no difference in the sex incidence of renal cortical necrosis (Duff and More, 1941).

\section{Summary}

A case of bilateral renal cortical necrosis is reported in which extensive bilateral renal calcification with a tram-line pattern was demonstrated during life and correlated with the morbid anatomical findings.

We wish to thank Professor C. Wilson for his helpful criticism. 


\section{H. G. LLOYD-THOMAS ET $A L .:$ TRAM-LINE CALCIFICATION IN RENAL CORTICAL NECROSIS}

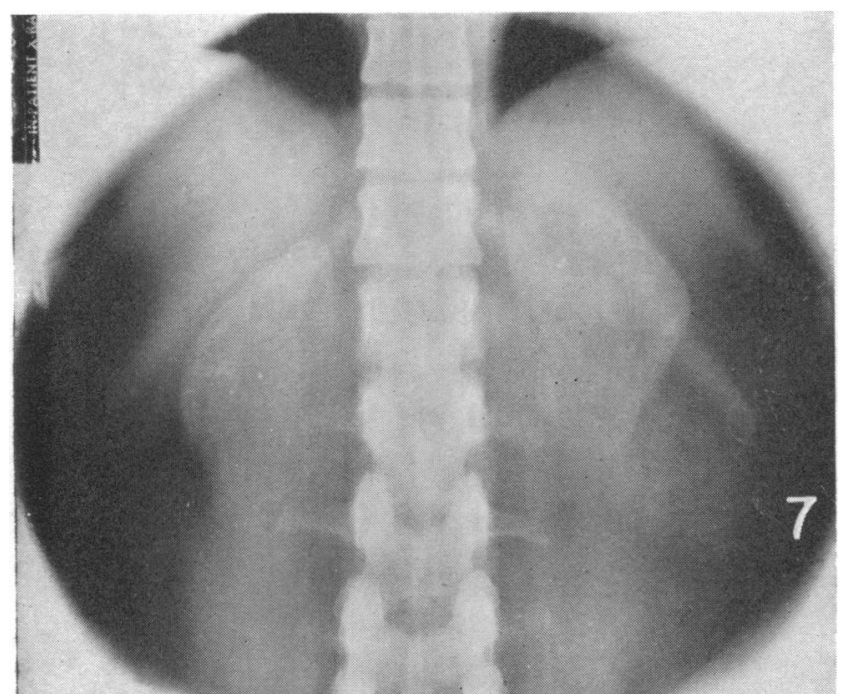

Fig. 1

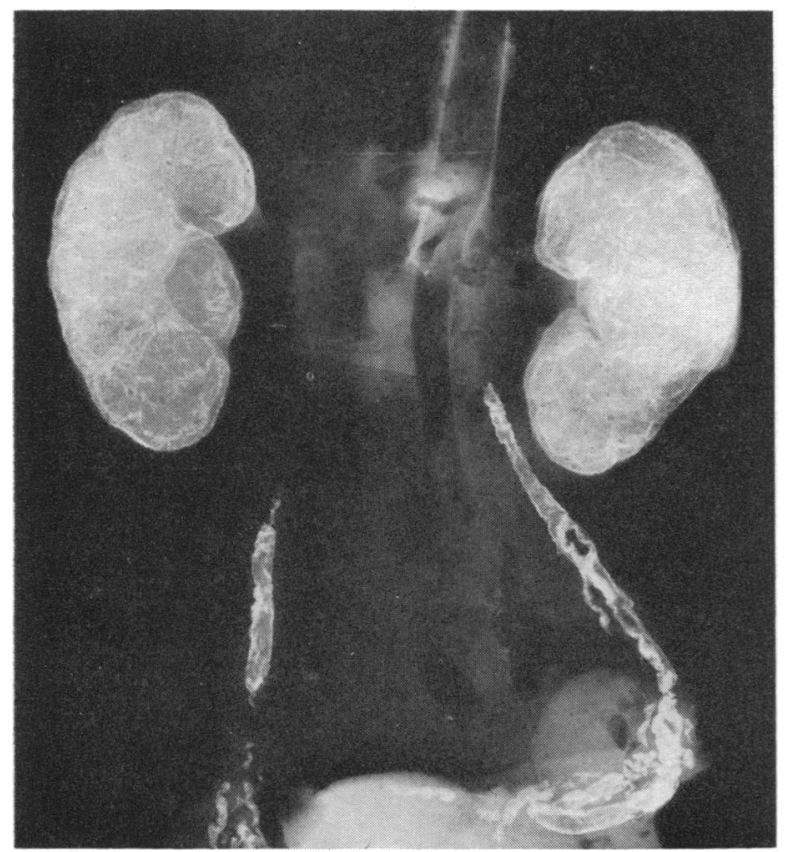

Fig. 2

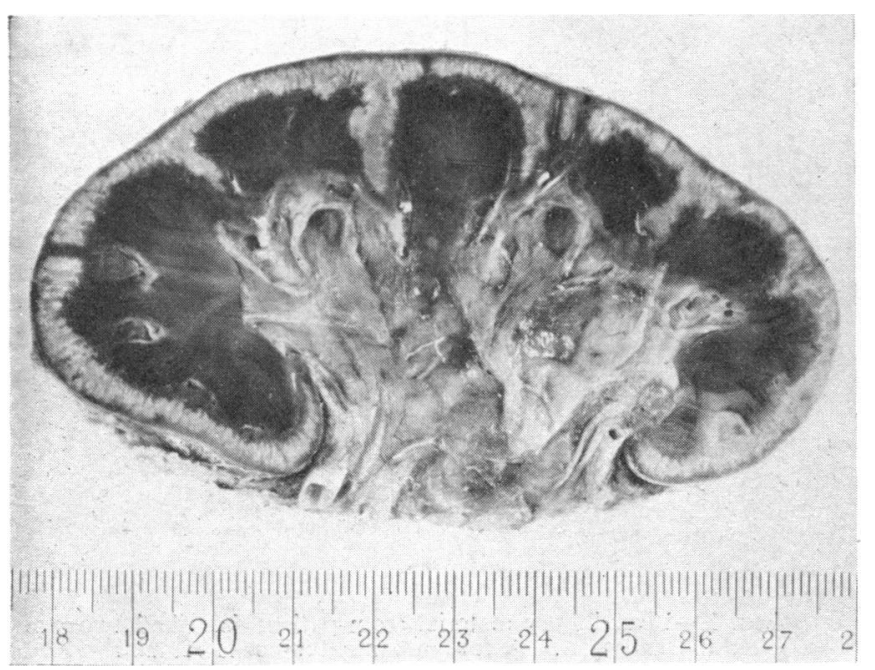

FIG. 3

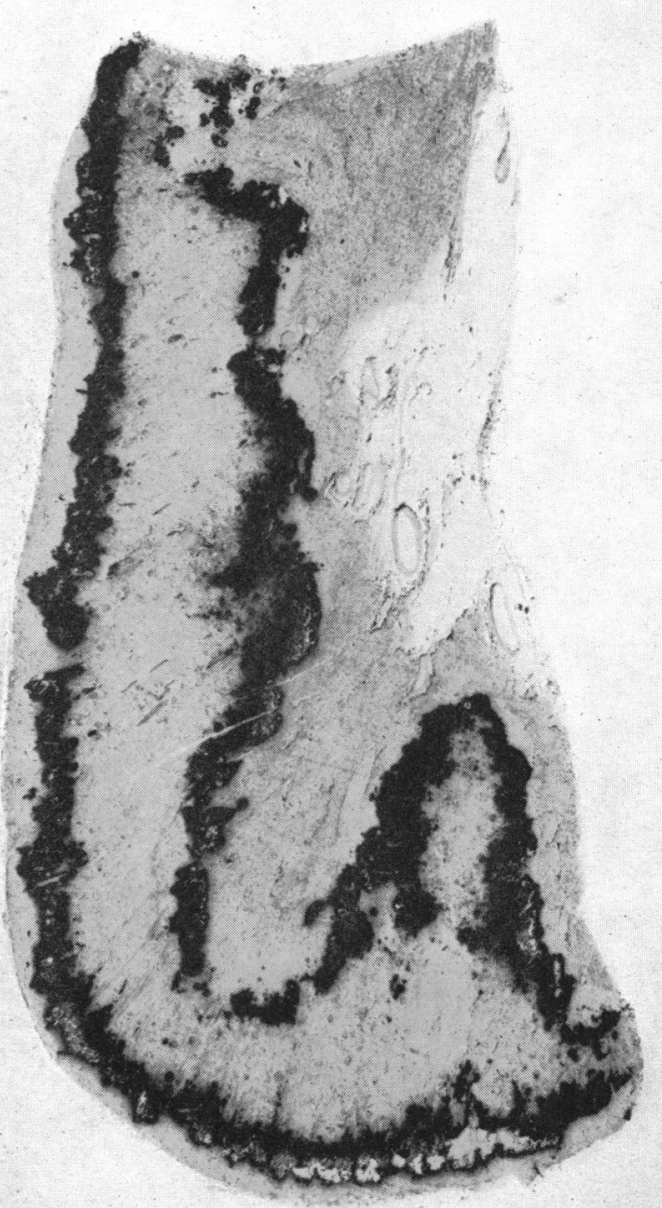

F10. 4

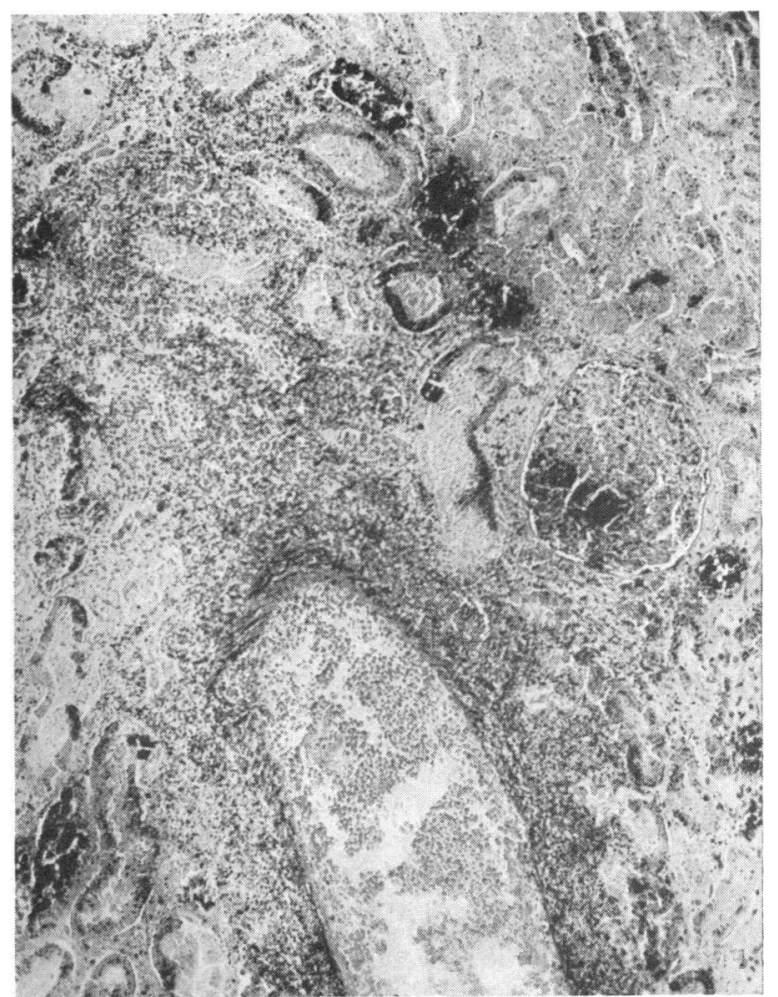

Fig. 5 


\section{DESCRIPTION OF SPECIAL PLATE}

FIG. 1.-Tomogram of kidneys. The double-line pattern of cortical calcification can be clearly seen. By inspection of tomographic cuts at other levels it was possible to trace the double-line pattern around most of the cortex. The double-line pattern was visible in the plain $x$-ray film, but was not dense enough to allow satisfactory reproduction.

FIG. 2.-Post-mortem radiograph of kidneys showing double-line pattern of calcification, which can be traced around almost the entire cortex. There is calcification of the thrombus in the ovarian veins.

FIG. 3.-Section through kidney showing extensive cortical necrosis.

FIG. 4.-Two bands of dense calcification are shown. Both the subcapsular tissue distal to the outer band and the medullary tissue proximal to the inner band contain renal elements which escaped the ischaemic process. Virtually all tissue between the two bands is necrotic. ( $(\times 4.5$.

FIG. 5.-Necrotic renal cortex showing calcification in glomerular tuft and dilatation of a necrotic interlobular artery. $(\times 100$.

\section{REPERENCES}

Akerren, Y. (1947). Acta med. scand., Suppl. 196, 273.

Alwall, N., Erlanson, P., Tornberg, A., Möell, H., and Fajers, C. M.' (1958). Ibid., 161, 93.

Arons, W. L., Christensen, W. R., and Sosman, M. C. (1955). Ann. intern. Med., 42, 260

Ash, J. E. (1933). Amer. J. med. Sci., 185, 71.

Boucot, N. G., Guild, W. R., and Merrill, J. P. (1957). New Engl. J. Med. 257, 416 .

Crook, A. (1927). Proc. roy. Soc. Med., 20, Part III, 1249.

De Graeff, J., and De Baan, P. (1959). Acta med. scand., 163. 341.

Duff, G. L., and More, R. H. (1941). Amer. J. med. Sci., 201, 428.

Geipel, P. (1925). Arch. Gynäk., 124, 231.

Gormsen, H., Iversen, P., and Raaschou, F. (1955). Amer. J. Med., 19, 209.

Grasby, E. D. Y. (1947). J. Obstet. Gynaec. Brit. Emp., 54, 203.

Hodson, C. J. (1959). Proc. roy. Soc. Med., 52, 669.

Jardine, R., and Teacher, J. H. (1911). J. Path. Bact., 15, 137.

Kellar, R. J., and Arnott, W. M. (1933). Edinb. med. J., 40, Trans. Edin. Obstet. Soc., 101.

Klotz, O. (1908). Amer. J. Obstet. (N.Y.), 58, 619.

Lauler, D. P., and Schreiner, G. E. (1958). Amer. J. Med., 24, 519.

McAlister, W. H., and Nedelman, S. H. (1961). Amer. J. Roentgenol., 86, 129.

Moëll, H. (1956). Acta radiol. (Stockh.), 46, 640.

- (1957). Ibid., 48, 355.

Ober, W. E. Reid, D. E., Romney, S. L., and Merrill, J. P. (1956). Amer. J. Med., 21, 781.

Scriver, W. de M., and Oertel, H. (1930). J. Path. Bact., 33, 1071.

Sheehan, H. L., and Moore, H. C. (1952). Renal Cortical Necrosis and the Kidney of Concealed Accidental Haemorrhage. Blackwell, Oxford.

Wells, J. D., Margolin, E. G., and Gall, E. A. (1960). Amer. J. Med., 29, 257.

Wolfson, A. (1932). Arch. Path. (Chicago), 13, 529.

Canada now has 21,000 active doctors, according to the 1962 edition of the Canadian Medical Directory. Another 1,300 doctors are retired or overseas. The Directory reports that the ratio of doctors to population has been rising steadily. To-day there is one active doctor for every 868 Canadians. Five years ago, in 1957, there was only one active doctor to every 970 . The province with the best ratio this year is British Columbia, where there is one active doctor for every 826 people. The lowest ratio is found in Newfoundland with one doctor to every 1,960 . There is a gradual trend towards more specialization in Canada. According to the Canadian Medical Directory only $30 \%$ of Canada's doctors were full-time specialists 10 years ago. This year $38 \%$ are full-time specialists. (Publishers, Seccombe House, 443 Mount Pleasant Road, Toronto, Canada. Price \$12.)

\section{BRETYLIUM TOSYLATE IN TREATMENT} OF SEVERE HYPERTENSION

\author{
BY
}

K. SOMERS, M.B., B.Ch., M.R.C.P., D.C.H.

Senior Lecturer in Medicine, Makerere University College Medical School, Kampala, Uganda

(From the Department of Medicine, Makerere University College Medical School, and the Medical Division, Mulago Hospital, Kampala, Uganda)

Ganglion-blocking drugs provide the most effective means of controlling severe hypertension. Their usefulness may be limited in some patients by the occurrence of the disabling side-effects of parasympathetic blockade. A drug that would block sympathetic activity without affecting parasympathetic function might be expected to show the hypotensive action of the ganglion-blocking agents without the unpleasant sideeffects. Bretylium tosylate has such properties. Introduced by Boura et al. (1959), bretylium tosylate blocks the sympathetic nervous system by its selective accumulation in sympathetic ganglia and post-ganglionic sympathetic fibres.

Following on encouraging reports of clinical trials (Boura et al., 1959; Dollery et al., 1960a) there has been a considerable correspondence (Turner and Lowther, 1960a, 1960b; Evanson and Sears, 1960 ; Lowe and Rosenheim, 1960 ; Somers, 1960a) recording unfavourable experiences with bretylium. Ultimately Dollery et al. (1960b) abandoned the use of bretylium because of the high incidence of drug resistance.

The findings reported in this paper refer to experiences with bretylium at an African hypertension clinic, the organization of which has been described elsewhere (Somers, 1960b).

\section{Clinical Observations}

Patients were admitted to hospital for initial assessment. After discharge they were followed up at a special clinic. A total of 29 patients $(11$ males, 18 females) were treated with bretylium tosylate. Their age distribution is shown in Table I. As previously reported from this clinic (Somers, 1959, 1960b, 1961), over half of the patients have chronic renal hypertension. This contrasts with experience in Western countries,

\begin{tabular}{|c|c|c|c|c|c|}
\hline Age of patients & $\begin{array}{l}\cdots \\
\cdots\end{array}$ & $\begin{array}{c}20-30 \\
6\end{array}$ & $31-40$ & $\begin{array}{c}41-50 \\
10\end{array}$ & $\underset{7}{\text { Over }} 50$ \\
\hline
\end{tabular}

TABLE II.-Clinical Findings in 29 Patients Treated with Bretylium Tosylate

\begin{tabular}{|c|c|c|}
\hline Diagnosis & No. of Patients & $\begin{array}{l}\text { No. with } \\
\text { Renal Failure }\end{array}$ \\
\hline $\begin{array}{l}\text { Essential hypertension } \ldots \\
\text { Renal hypertension : } \\
\text { Chronic glomerulonephritis } \\
\text { Chronic pyelonephritis } \\
\text { Toxaemia of pregnancy }\end{array}$ & $\begin{array}{r}15 \\
3 \\
10 \\
1\end{array}$ & $\begin{array}{l}1 \\
1 \\
3 \\
0\end{array}$ \\
\hline Total $\ldots$ & 29 & 5 \\
\hline
\end{tabular}

where essential hypertension is the more common. In the series, essential and renal hypertension were equally represented (Table II). Five patients showed evidence of chronic renal failure-that is, had blood-urea levels persistently in excess of $60 \mathrm{mg} . / 100 \mathrm{ml}$. No patient with blood-urea levels persistently in excess of $150 \mathrm{mg}$./ 